\title{
Review of Effective School Supervision Practice in Remote/Disadvantaged Area: A National and International Perspective
}

\author{
Ikhfan Haris \\ Faculty of Education \\ Universitas Negeri Gorontalo \\ Gorontalo, Indonesia \\ ifanharis@ung.ac.id
}

\author{
Fory A. Naway \\ Faculty of Education \\ Universitas Negeri Gorontalo \\ Gorontalo, Indonesia \\ ifanharis@ung.ac.id
}

\author{
Wiwy Triyanty Pulukadang \\ Faculty of Education \\ Universitas Negeri Gorontalo \\ Gorontalo, Indonesia \\ ifanharis@ung.ac.id
}

\begin{abstract}
School supervisors have an important role to play in supporting principals and teachers to improve the quality of education delivered in schools, and in strengthening the capacity of principals and teachers to deliver on this goal. Schools in remote and in the outermost areas may only receive one supervision visit per year-if at all. This paper is dealing with a review of effective supervision model for school supervision in remote/disadvantaged area in national and international perspectives. The paper will be focused on the approaches that have been applied by other countries, as well as in Indonesia, that may be applicable for school supervision in Indonesia's 3T (Tertinggal, Terdepan, dan Terluar) or special regions. In addition, the paper will examine and provide information on approaches to school supervision for remote, disadvantaged and border/outlying areas utilized in other countries and it may be adopted or adapted to the unique environment in the ' $3 T^{\prime}$ ' areas in Indonesia.
\end{abstract}

Keywords-effective, model, supervision, education, school, special regions $(3 T)$

\section{INTRODUCTION}

One of the Indonesian nation's development orientations is the development of special regions [1]. Special regions are part of priority areas categorized as regions which are underdeveloped, remote, and in outer/frontier (3T areas). 3T is abbreviated from Tertinggal, Terdepan, dan Terluar; literally means; the Frontier, Outermost and Disadvantaged Area. Areas classified as remote (terpencil), disadvantaged (tertinggal) and on Indonesia's borders or outlying (terdepan/terluar) [2].

This development orientation is stated in the Government's National Priority Agenda i.e. to develop Indonesia from the suburban areas by strengthening regions and villages within the Republic of Indonesia [3]. This is part of the equal national development pride. For that, all development sectors must be integrated to improve public welfare and prosperity, especially in the $3 \mathrm{~T}$ regions related to the education sector.

Education development is included in one of the development sectors in special regions that should be developed and managed contextually, according to the $3 \mathrm{~T}$ region situation and condition. Education quality improvement in each educational unit in the special regions, both massively and organizationally, is focused on the role of the principal. The principal is a teacher with additional tasks in a principal position. This means, aside from teaching tasks, the person also bears tasks as a school leader. On the other hand, development among schools is largely done by the school supervisory function [4].

The school supervisor is part of the overall educational personnel that is strategically positioned in national education quality improvement [5]. To achieve its main task, the school supervisor must be equipped with personal competencies such as managerial and academic supervision, education evaluation, research and development and social capabilities [6].

In Indonesia, the problem of education in special regions is more complex than that in other advantage areas, among them shown by the data of school accessibility by student or disparity/education equality [1]. This paper provides information on approaches to school supervision for remote, disadvantaged and border/outlying areas utilized in other countries and in Indonesia that may be adopted or adapted to the unique environment in the ' $3 \mathrm{~T}$ ' areas.

\section{SCHOOL SUPERVISION: CURRENT ROLES AND IMPLEMENTATION}

School supervisors have an important role to play in supporting principals and teachers to improve the quality of education delivered in Indonesia's schools, and in strengthening the capacity of principals and teachers to deliver on this goal [5].

In Indonesia's "3T' areas" extremes of geography and lower levels of financial and human resource capacity are preventing effective supervision occurring. 3T' areas are areas classified as remote (terpencil), disadvantaged (tertinggal) and on Indonesia's borders or outlying (terdepan/terluar) [2]. Schools in remote and in the outermost areas may only receive one supervision visit per year - if at all. But if the Ministry's aim to reduce the disparity between ' $3 \mathrm{~T}$ ' areas and the rest of Indonesia is to be achieved, the school supervisor function (as one key input to better schools) needs to be performing much more effectively than it is currently.

Education supervision is a strategic process that assures quality education for all Indonesian students. With the support of the School Supervisor, the school principal, teachers and community ensure students develop to their full potential to become faithful religious citizens who believe in God Almighty. Students graduating will be healthy, educated, skilled, creative, and independent citizens who are democratic, accountable, and possess noble intentions that embrace the cultural systems of their tribe [7]. Through the 
process of formative supervision, educational organizations including schools commit to contributing to bringing the nation to its ideology through the achievement of the eight education national standards.

School supervisors are responsible for reviewing principal and teacher performance, student academic and wellbeing outcomes, curriculum implementation approaches, financial and administrative management, maintenance of buildings, the health of the learning and work environment, and adequate resourcing of the school [6]. They will evaluate and make judgments referencing the Ministry of Education and Culture policy and direction, the National Education Standards, the National Education Minimum Standards, and the National Principal and Teacher Standards. They will use the Ministry of Education and Culture guidelines for Principal and Teacher Appraisal in making judgments about overall performance, as well as the principal and individual teacher's impact on school improvement and student improvement annually.

The school supervisor will analyze data and review evidence to ensure their judgments and those of the school principal, teachers, and community members are transparent and in line with public accountability principles (Permenpan RB No. 21/2010 Article 188 point 1 \& 2) [8]. With the support of the community, they will provide constructive feedback and formal recommendations to the appropriate local governing bodies and Divisions (Law No. 20/2003 Sisdiknas Article 66) [7]. The school supervisor is responsible for providing leadership and guidance to the school principal, teachers and community members, and delivering professional learning programs in regards to the Ministry of Education and Culture and school priorities.

The principal is responsible for leading the academic program and management of the school. They liaise with the School Supervisor, their staff and the community to ensure rigor, transparency and quality school and student outcomes [2], [7]. They are responsible for school supervision program plans, implementation, and evaluation. Supervision is conducted collaboratively through face to face meetings, observation and the through the gathering of evidence to inform judgment. The principal is responsible for leading the management of the school through the development of the school plan with reference to the Minimum Service Standards, National Education Standards, and the National Principal and Teacher Standards.

\section{SUPERVISION OF SCHOOL}

School supervision leads to improved teaching and learning via two intermediate mechanisms: (1) setting expectations for schools and stakeholders. Research shows that supervision criteria and procedures influence schools and their stakeholders to align their views/beliefs and expectations of what constitutes good education to the standards in the supervision framework [9]. Schools and stakeholders are expected to use these standards in their daily management of, and or activities in the school, and (2) schools and stakeholders accepting supervision feedback. Schools align their education to the standards they failed to meet during the latest supervision visit as outlined in supervision feedback. Schools use supervision feedback when conducting self-evaluations and when taking improvement actions. Likewise, stakeholders are expected to use the supervision feedback (as publicly reported) to take actions that will motivate the school to improve [9].

These two intermediate mechanisms can improve the self-evaluations of schools; building schools' capacity to improve that, in turn, will lead to more effective teaching and learning conditions. Likewise, improvement actions will (when successfully implemented) lead to more effective school and teaching conditions. In turn, this process, should, logically, result in higher student achievement.

A review conducted by the Ministry of National Education in 2015 regarding school supervisors in special regions (3T) identified several issues, among others: (1) lack of capacity building for units of education by the school supervisor; (2) lack of school supervisor visits to target schools due to geographical and infrastructure obstacles, such as the surrounding terrain, distant school location, and limited transportation; and (3) lack of operational funds to implement supervisory tasks in the special regions [10], [11]. In addition, the review also identified causes for supervision problems in the special regions, such as (1) number of school supervisors is less compared to the number of target schools which will supervise by supervisor; (2) the education background and work experience of supervisor do not match the main tasks of a school supervisor; (3) the local Provincial/ District Education Office (PEO/ DEO) offers not enough opportunity to train and build the competency of school supervisors; (4) lack of operational funding for school supervision; (5) lack of monitoring on Minimum Service Standard (MSS) for the implementation of school supervision by the central and local government; (6) lack of community/ school committee involvement in supporting the school supervision implemented in schools; (7) the distance between target school and school supervisor's office (local $\mathrm{PEO} / \mathrm{DEO}$ ) and (8) the limited transportation facilities for school supervision [10], [11].

\section{INTERNATIONAL AND LOCAL APPROACHES IN SCHOOL SUPERVISION: AN EXAMPLE}

These approaches acknowledge the planning to date by the Special Regions Committee. These approaches recognize the geographical isolation of the Special Regions as well as the significant budget challenges faced by the School Supervisor, the distances to schools and the transport challenges, and the lack of infrastructure to support a quality supervision process.

They emphasize that ICT in education has a multiplier effect throughout the education system, by enhancing learning and providing students with new sets of skills; by reaching students with poor or no access (especially those in rural and remote regions); by facilitating and improving the training of teachers; and by minimizing costs associated with the delivery of traditional instruction.

Beyond sub-regional differences, the internal digital divide of developing countries has also increased significantly as urban centers quickly adopt ICT while it remains out of reach for rural and remote regions. Bearing these caveats in mind, ICT in education in Asia can be viewed from two very different perspectives. The first reflects a development discourse that stresses the role of ICT in eliminating the digital divide by reaching the unreached and providing support to those who cannot access essential infrastructure, trained teachers and other quality educational 
resources. The second perspective adheres to an e-learning paradigm and is a response to the emerging knowledge society where ways of teaching and learning are evolving at a rapid pace to foster learner-centric educational environments, which encourage collaboration, knowledge creation and knowledge sharing. While countries are admittedly at different stages of integrating ICT in education, ultimately both perspectives will be increasingly relevant for countries in Asia.

The following is a summary of approaches that have been applied by other countries, as well as in Indonesia, that may be applicable for school supervision in Indonesia's 3T or special regions. Information is provided on the approach, which countries it has been used in, whether it is used for managerial or academic supervision, and requirements for implementation.

\section{A. Professional Learning Approaches}

Professional learning is imperative in all professional organizations and vital in schools where school and student improvement policies and programs continue to be updated. Remote principals and staff meet the daily challenge of not only being isolated geographically but also having minimal access to regular electricity, and communication and information technologies [12], [13]. In countries that face such issues the following solutions have been implemented:

- Philippines: Microsoft has a project for rural areas where content and curriculum can be downloaded to a Windows phone and then played through a television or other device and reloaded when educators travel to a larger city.

- Indonesia: Microsoft has partnered with the Ministry of Education and Culture on the $e$-Sabak project for student textbooks. This currently includes using One Note to access information anywhere, anytime and load to One Drive when there is an opportunity to do so. This same project would enable professional learning programs to be loaded regularly to a school or teacher laptop and smartphone. Updates could be completed each time the Supervisor meets with the Principal allowing new material to be shared every three to four months.

- In Indonesia, Zenius has developed an online platform for teacher professional development. The platform provides a mix of free and paid content: http://zeniusprestasi.com.

- In Australia, apps are loaded onto smartphones that allow exemplars of:

- $\quad$ Teacher and Principal standards

- Curriculum implementation

- Quality teaching processes

- New policy implementations e.g. child safety

- In Australia, the Solomon Islands, Tonga and Indonesia television such as TV Edukasi is used to distribute professional content via satellite. TVEdukasi (TV-e) broadcasts animated units of instruction focused on the primary curriculum. The e-dukasi.net Website offers forums, recommended
Websites, learning activities and exam-preparation resources for Indonesian secondary students. This tool could also be used to facilitate content for principals and teachers.

- In Australia, the Solomon Islands, Tonga, Fiji, and Vanuatu radio is used to distribute professional content.

- In many countries, PD on a Stick (USB) has been used and this could be transferred regularly by the School Supervisor or by mail or by drone.

- In Bangladesh - with support from the nongovernmental development organization, BRAC - introduced 17 mobile ICT laboratories containing laptop computers, cameras, multimedia projectors, etc. to cover 1,000 schools in remote areas [12]. BRAC introduced Multimedia Classrooms in secondary schools, using one laptop with an internet connection and a multimedia projector per classroom. This approach proved to be much more affordable than a full-fledged computer lab and thus economically more feasible.

- In Sri Lanka - through its Nensala Project, Sri Lanka established over 700 rural telecenters or "Nensalas", which are managed and supervised by the Nensala Community Development Task Force to build ICT skills and impart ICT education in school curricula [12].

\section{B. Approach with Offsite Meetings with Principals}

It is usual that the school year starts with the School Supervisor meeting with their school principals together at an agreed site for 2-3 days. This could be at the district education office, school cluster, or another agreed location. During this time new policy and practices are discussed, professional development is completed together, technologies are updated, data collections and evidence gathering timelines are established for the year, and individual meetings are completed as part of the Principal Appraisal process. This meeting time provides quality input for the first face to face school-based meeting.

These meetings could be held twice a year to (a) provide a network for principals in which to share practice; (b) disseminate Ministry of Education and Culture programs and policies; (c) fulfill supervision requirements particularly in regards to the National Education Standards and the Principal and Teacher Standards and (d) complete professional capacity building exercises coach principal supervisory practices establish formats for calendared online/offline meetings (e.g. for coaching, providing advice) when they return to school.

\section{Approach with Using Data Collection and Analysis for School Improvement}

In Indonesia data is currently collected through 31 instruments along with observations collected whilst at the school. The Committee has already identified that these data collections are entered generally on paper by the school and the Supervisor. The Supervisor then spends an extraordinary amount of time manually analyzing data into a report that is lodged with the local governing authority. The committee noted that this report is retained by the local governing 
authority, is not shared with the Ministry of Education and Culture and is not acted upon. The report has no impact and is a redundant exercise.

In Australia and in a number of countries such data is loaded into a database that as its endpoint provides a single point of truth for the student, the principal, the teacher, and the supervisor. That means that any data collected about an individual is attributed back to that individual. This in time provides a cumulative record about each student, principal, teacher, and supervisor and provides agreed evidence on which to make judgments.

Technically data mining tools can be loaded as apps to the principal's laptop and downloaded when they come to the meetings twice a year. Data can also be uploaded when the School Supervisor visits the school. There is a backup server in the school. Cloud technologies should be considered. Alternatively are: (a) if data loads are required more regularly Drones can pick up and drop off memory sticks and materials up to 2 kilograms, or it can be sent by mail or via other school personnel visiting district centers, and (b) data can be stored offline until online capability is available as mentioned before.

This kind of transmission is seen as more helpful as in areas such as Papua where the Telkom's (Indonesian telecommunication) transmission capacity for the entire province is $20 \mathrm{Mbps}$ - compared, say, with a typical OECD residential connection of $8 \mathrm{Mbps}$ [12]. As a result of these factors, data transfer speeds on the internet are slow and of poor quality at all times, compared to international and even national norms, and in many instances make Web access impossible. By passing the network for such things as data transmission is seen as sensible enabling small opportunities for internet users to be used for other communication priorities.

\section{Use of Community to Monitor School Accountability and Performance as Supervision Approach}

KIAT GURU (Kinerja dan Akuntabilitas Guru - Teacher Accountability and Performance). The purpose of KIAT Guru (a TNP2K initiative) is to improve basic education service delivery and student learning outcomes in rural and remote areas. As this is a complex endeavor influenced by myriad factors, experimentation, adaptation, and learning were essential to developing and scaling up appropriate solutions. TNP2K (National Team for Acceleration of Poverty Reduction) is an institution established to coordinate the acceleration of poverty reduction across sectors and stakeholders. Established by the Decree of the President of the Republic of Indonesia Number 15/ 2010, TNP2K sits under the Secretariat Office of the Vice President of the Republic of Indonesia. To this end, KIAT Guru implemented several interventions that combine the following two mechanisms: Community Empowerment Mechanism (CEM), which provides community members with an explicit role to monitor and evaluate teacher service performance, and to ensure teacher accountability; and Pay for Performance Mechanism (PPM), which tie payment of special allowance with availability and/or quality of teacher service delivery.

TNP2K partnered with the Ministry of Education and Culture and the district governments of Ketapang (West Kalimantan), Kaimana (West Papua) and Keerom (Papua).
The Pre-Pilot Phase developed, tested and improved two main implementation mechanisms and five evaluation instruments, with inputs from stakeholders at different stages. This phase was conducted between March and October 2015.

In order to send information and reports to and from remote villages to the district and/ or national offices, and to collect, store and manage them, several alternatives were considered, particularly for areas with no or unstable telecommunication signal. At the beginning of the design, the use of the following interconnectivity and devices were considered according to the following priority: (1) in villages where there are $\mathrm{Wi}-\mathrm{Fi} / 3 \mathrm{G}$ signal, transfer of information and report to be managed using mobile-phone; (2) where there is a telecommunication signal, transfer of information in SMS to be managed using a mobile phone; (3) where there is no telecommunication signal, transfer to be conducted through Single Side Band (SSB) radio or other locally utilized telecommunication; (4) at the worst case scenario, subdistrict facilitators to collect the information through USB, compile it in his/her laptop and send the information when they find the connection, and (5) at the very remote area there is option to provide portable and Fixed Satellite.

TNP2K developed, implemented, and revised four innovative mechanisms and instruments to support the interventions and evaluations, with inputs from stakeholders. They included: (a) Government regulations to enable community input and evaluation of education service delivery and payment of APBD teacher allowances based on performance; (b) KIAT Kamera, a tampered-proof Androidbased application that provides accurate data of daily teacher attendance; (c) Community Score Card (CSC) that specifies between 5 to 8 indicators of education service availability and quality; and (d) Student Learning Assessment instruments, consisting of simple diagnostic and evaluation instruments for basic literacy and numeracy, which place student's level of competency along a continuum based on 2006 national curriculum.

In relation to staff attendance, a Manual Absence Form (MAF) was utilized, as mandated by the district governments and attendance was recorded on a daily basis using KIAT Kamera, a tampered-proof Android-based camera application. At the end of each month, the community representatives filled out School providers' Presence Verification Form (SPVF) that crossed checked the results from KIAT Kamera against MAF. The MAF is also needed to encounter possible malfunctioning of KIAT Kamera. For evaluating the quality of service indicators, the community representatives were informed with a few means to monitor teacher service performance: by interviewing students, by conducting direct observations, or by checking on written documents. Their evaluations were recorded into the CSC on a monthly basis.

Evidence from the pilot showed that teacher presence in the classroom and student learning outcomes in 31 participating schools improved. In addition, surveys conducted by PSKK-UGM (Pusat Studi Kebijakan dan Kependudukan-Universitas Gadjah Mada) indicated that teacher presence in classrooms has increased from $48.5 \%$ to $60.1 \%$ in Keerom and Ketapang. In 31 participating schools, learning outcomes in basic literacy indicated that more students achieved grade level competencies, with an increase from $16.9 \%$ to $35.3 \%$. Student illiteracy had decreased from 
$27.9 \%$ to $12.7 \%$. In basic numeracy, more students achieved grade level competencies, with an increase from $6.2 \%$ to $22.2 \%$. Student innumeracy had decreased from $5.7 \%$ to $1 \%$. The Pre-Pilot Phase found that communities need to have sufficient willingness to participate in improving education service delivery [14].

Based on the KIAT Guru Pre Pilot, Ministry of Education and Culture has requested KIAT Guru to be scaled up to a Pilot Phase to provide evidence-based policy recommendations for the most effective implementation options to improve basic education service delivery in rural and remote areas. KIAT Guru Pilot Phase will be implemented in 200 rural and remote villages in five districts starting in mid-2016 until December 2017.

\section{E. Approach to Scheduling Visits of Schools to Target Schools/Teachers in Most Need of Improvement}

A report provided to the Zanzibar' Ministry of Education and Vocational Training recommended a program of school supervision using a two-phased approach to implementation [15]. The Solomon Islands Ministry is also exploring a twophase approach with the first phase to embed and pilot the new supervision model, and the second phase to move to full implementation [16].

The first phase proposed in Zanzibar reflects the processes already embedded in Indonesia. The development of legislation specifying the tasks and roles of the school supervisor, how the school supervisor evaluates schools, which supervision standards they include in their work, which consequences or follow-up are related to their work and which budget is guaranteed to perform these duties have been implemented [15]. The first phase also proposed training for school supervisors on how to objectively evaluate the quality of teaching and learning in schools, how to provide effective feedback and how to store and analyze data on quality of schools to evaluate trends in specific quality areas over a longer period of time. They also identified the need for an effective feedback and reporting mechanism in which supervision feedback is differentiated and provided to different stakeholders and followed up in repeated supervision visit.

The second phase proposed differentiated scheduling of visits to schools to target schools and teachers most in need of improvement, as follows: (1) scheduling visits to schools. An effective schedule of supervision visits targets the schools that are most in need of improvement and provides information to the actors in these schools that are in charge of implementing these improvements. The supervisor develops a schedule of regular supervision visits to generate a database of school quality. This database is used to target customized supervision visits to failing schools in which specific standards are evaluated. (2) Scheduling of visits of individual teachers: observations of teachers during school visits need to be scheduled in such a way to provide an assessment of the quality of teaching on the school level as well as provide assessments of (some) individual teachers. The first assessment modus of the quality of teaching of the school requires the selection of a representative sample of teachers, while the second modus could also target specific teachers (e.g. new teachers, teachers who want to be promoted to principals or section leaders, or teachers who have been identified as failing in previous visits).
In scheduling a visit to schools, the school supervisor of education needs to have an overview of the teachers in the school according to subject, experience, prior performance of teachers, and potential career development wishes of teachers to prepare a smart schedule of which teachers to observe that meets both selection criteria. (3) Use of consequences (and reward) to encourage change: Each supervision visit should have clear consequences for schools and teachers to promote impact of supervisions. Schools and teachers who perform well should be rewarded and appreciated. Rewards can include a certificate of appreciation/reward for schools and/or teachers and outstanding performance should be awarded through additional increments to teachers' and principals' salaries.

Consequences to address failure in schools should follow an 'intervention pyramid' where the first assessment of failure leads to support, advice and additional monitoring. Also, the principal needs to address how he/she will improve any shortcomings in the school's development plan. In case the failure persists, more severe sanctions will be enacted. These may include withholding an annual increment on teachers' and/or principal' salaries. Such consequences should only be enacted when the failure is attributable to the school/teachers, and not for example to factors outside of the school's/teacher's control (e.g. lack of textbooks or lack of teachers). (4) Feedback: use information from regular supervision visits to publish an annual supervision report on the state of education for Ministry of Education and Culture as well as individual school reports.

\section{CONCLUSION}

This paper presents some examples of school supervision models used in other countries that could adapt and/or adapt to improve the effectiveness of school supervision in remote (terpencil) and disadvantaged (tertinggal) schools, and those schools lying on and near Indonesia's borders (terdepan/terluar). These are known as 3T areas. The review has considered a range of national and international examples. The review assessed country reports and various literature evaluations of school supervision from Australia, Bangladesh, the Philippines, the Solomon Islands, Srilanka, and Zanzibar as well as Indonesia. In reviewing the policies and practices from other countries it became quickly apparent that many are on the same learning journey as Indonesia and that Indonesian supervision policies and guidelines were comparable with many of these countries.

\section{REFERENCES}

[1] B. P. Statistik and U. Bappenas, "Proyeksi Penduduk Indonesia 20102035," Jkt. Badan Pus. Stat., pp. 1-472, 2013.

[2] R. Indonesia, "Peraturan Presiden Nomor 131 Tahun 2015 tentang Penetapan Daerah Tertinggal Tahun 2015-2019," Sekr. Kab. RI Jkt., 2015

[3] J. Widodo and J. Kalla, "Jalan Perubahan untuk Indonesia Yang Berdaulat," Mandiri Dan Berkepribadian-Visi Misi Dan Program Aksi, 2014.

[4] R. I. Kemendikbud and R. I. Kemenag, Pengembangan Keprofesian Berkelanjutan Kepala Sekolah/Madrasah. Jakarta: Pusat Pengembangan Tenaga Kependidikan, Badan PSDMPK dan PMP, 2014.

[5] N. Sudjana, "Pengawas dan Kepengawasan: Memahami Tugas Pokok, Fungsi, Peran dan Tanggung Jawab Pengawas Sekolah," Bekasi Binamitra Publ., 2012.

[6] D. T. Kependidikan, Panduan Pelaksanaan Tugas Pengawas Sekolah. Madrasah, 2009 
[7] P. R. Indonesia, "Undang-undang Republik Indonesia nomor 20 tahun 2003 tentang sistem pendidikan nasional," Jkt. Pemerintah Repub. Indones., 2003.

[8] I. L. Lubis, "Implementasi kebijakan beban kerja pengawas sma di kabupaten padang lawas (studi tentang kebijakan Permenpan RB no. 21 tahun 2010 pasal 6 tentang beban kerja pengawas)," PhD Thesis, UNIMED, 2016.

[9] M. C. Ehren, H. Altrichter, G. McNamara, and J. O'Hara, "Impact of school inspections on improvement of schools - describing assumptions on causal mechanisms in six European countries," Educ. Assess. Eval. Account, vol. 25, no. 1, pp. 3-43, 2013.

[10] K. P. Indonesia, "Laporan Akuntabilitas Kinerja Kementerian Pendidikan dan Kebudayaan 2015," 2016.

[11] A. R. Baswedan, "Gawat darurat pendidikan di Indonesia," in The Emergency of Indonesian Education]. A paper delivered at the meeting between Ministry and Head of Education Offices Indonesiawide in Jakarta, on December, 2014, vol. 1.
[12] O. Publishing, OECD science, technology and industry outlook 2010. OECD Pub., 2010.

[13] W. B. Group, World development indicators 2014. World Bank Publications, 2014

[14] A. Dwiyanto, Teladan dan pantangan dalam penyelenggaraan pemerintahan dan otonomi daerah. Pusat Studi Kependudukan dan Kebijakan, Universitas Gadjah Mada, 2003.

[15] A. S. Suleiman, Y. Yat, and I. Iddrisu, "Education Policy Implementation: A Mechanism for Enhancing Primary Education Development in Zanzibar," Open J. Soc. Sci., vol. 5, no. 3, p. 172, 2017.

[16] H. Pillay, S. Carrington, J. Duke, M. Tones, S. Chandra, and J. Heeraman, Mobilising school and community engagement to implement disability-inclusive education through action research: Fiji, Samoa, Solomon Islands and Vanuatu. Queensland University of Technology, 2015. 